\title{
Introduction / Présentation
}

\author{
Jennifer McWeeny
}

We live in a time where our modes of reading, writing, and thinking are changing rapidly. Rates of change and the impacts of these changes are also variable across cultures, geographies, social locations, socio-economic classes, and generations. Many contemporary readers feed primarily on digital snippets, sound bites, and headlines from the internet, and never find the time to have what was once considered to be a complete (literary) meal. The sensuality of reading in the twenty-first century is dominated by screens, clicks, smooth plastics, and metals, rather than the organic textures and vegetable scents of printed pages from bygone times.

New writing practices have developed in response to new reading practices. Twenty-first century words are frequently crafted with a virtual readership in mind; authors expect that their work will be read online in real time and reviewed just as quickly. Titles of books and articles are now decided in virtue of their "searchability" in digital databases instead of for their poetry or provocation. The art of sending hand-written letters with paper and ink is nearing extinction. Promotion and dissemination of writing on platforms such as Twitter and Facebook have become part of writing itself; in "marketing" her work, an author frames and shapes its content.

These transformations in our modes of communication and expression are driven as much by the social, political, and aesthetic character of twentyfirst century life as they are by the steady stream of new technologies and porous international borders guaranteed by a global economic structure. Rightwing thought and left-wing thought are head-to-head in the race to determine the social and political landscapes of the next millennium. With the stakes so high, and with oppositional views in such close proximity to one another, social postures that evade political commitment and self-reflection are gaining in popularity. The practical demands of a post-industrial capitalist workplace whose most important product is ethereal flows of information likewise keep the average citizen disconnected, disengaged, and in various states of "techno-hypnosis." A number of impending dooms such as climate

1 Nolen Gertz, Nihilism and Technology, London, Rowman \& Littlefield International, 2018, pp. 6o-63. 
change, species extinction, and unmanageable waste and pollution, as well as the prevalence of violence, war, income inequality, and political turmoil contribute to moods of anxiety, depression, and impotence among young people and others. Again, such characteristics of twenty-first century life are differently distributed and experienced across geographies, cultures, social locations, and generations.

Nearly twenty years into the new century and just a few ticks into the third millennium, Simone de Beauvoir's writings have never been more relevant. Contemporary interest in Beauvoir has been growing rather than declining, her place in academic canons and in the intellectual and political fabrics of our time crystalizing rather than dissipating. ${ }^{2}$ Jean-Louis Jeannelle's recent exclamation aptly captures the energy of the moment: "Quelle révolution dans le regard porté sur l' œuvre de Simone de Beauvoir!"3 In the past twelve months, at least six international conferences focused on the seventieth anniversary of Le Deuxième Sexe and a large number of books and journal special issues on Beauvoir were published. ${ }^{4}$ Beauvoir's ideas are being invoked in the context of different grassroots women's movements around the world and put into conversation with the experiences of people from the Global South, people of color, and people subject to neo-colonialism and imperialism with

2 Examples of Beauvoir's growing place in academic canons include the publication of the Pléiade edition of six volumes of Beauvoir's Mémoires; the inclusion of Mémoires d'une jeune fille rangée on the 2018-2019 French agrégation examination in lettres modernes; the recent publication of the seventh and final volume of The Beauvoir Series from Illinois University Press, a series edited by Margaret A. Simons and a team of international scholars that has introduced Anglophone audiences to many of Beauvoir's lesser-known texts; and the tenyear anniversary of the second English translation of The Second Sex by Constance Borde and Sheila Malovany-Chevallier.

3 Jean-Louis Jeannelle, "Introduction. 'Beauvoir aujourd'hui,'” in Simone de Beauvoir. "Mémoires d'une jeune fille rangée," dir. Jean-Louis Jeannelle, Rennes, Presses Universitaires de Rennes, coll. "Didact Concours," 2018, 7-17, p. 7 .

4 Recent conferences include: "Penser avec Simone de Beauvoir aujourd'hui," Paris, France, October 11-13, 2018; "The Legacy of Simone de Beauvoir and Post/Feminist Condition in the 21st Century," Vilnius, Lithuania, October 18-19, 2018; "Contemporary Receptions of Simone de Beauvoir's Work: France, Italy, and Spain 1968-2018," Nice, France, December 3-4, 2018; "First International Simone de Beauvoir Congress: Commemoration of The Second Sex Seventieth Anniversary," São Carlos, Brazil, June 12-14, 2019; "Simone de Beauvoir's The Second Sex," Oxford, United Kingdom, July 2-3, 2019; "Le Deuxième Sexe Seventy Years On: Reading Beauvoir around the World," Atlanta, Georgia, USA, October 25-26, 2019. See also the following journal issues: "Simone de Beauvoir. Réceptions contemporaines," special issue, Cahiers Sens Public, vol. 3-4, no. 25-26, 2019; "Simone de Beauvoir," virtual issue, French Studies, 2018, https://academic.oup.com/fs/pages/simone_de_beauvoir_virtual_issue. 
increased frequency. ${ }^{5}$ Still more developments could be mentioned. ${ }^{6}$ A renaissance in Beauvoir studies is upon us.

As part and parcel of this renaissance, and in response to the expressive needs and contours of the twenty-first century, Simone de Beauvoir Studies has been reborn. During the hiatus that followed the retirement of Yolanda Patterson, the journal's Editor-in-Chief and President of the International Simone de Beauvoir Society for more than thirty years, members of the Society came together to transition the Society and its journal into a new era. Tove Pettersen details many of these changes in the first piece in this issue, "A Word from the President of the Society / Le Mot de la Présidente de la Société." This inaugural issue of the redesigned Simone de Beauvoir Studies titled "The New Face of Simone de Beauvoir Studies/ Études sur Simone de Beauvoir: un nouveau regard" is a consequence of these labors, which are driven by a desire to accommodate the unique demands of contemporary times while also not losing sight of our history, of how we have become what we now are.

The renewed Simone de Beauvoir Studies is less a journal about Simone de Beauvoir and her writings than it is publication that aspires to cultivate her literary, political, philosophical, and editorial visions. We are a multidisciplinary and multigenre journal that speaks with multiple voices to the most pressing issues of our time. This variety is threaded together with lines of Beauvoir's interests - political issues that she cared about, philosophical themes that she explored, methods of writing that she developed, attitudes of authenticity, courage, openness, and self-reflection that she demonstrated.

Simone de Beauvoir Studies is premised on the idea that the more diverse perspectives and styles of expression included in a conversation, the richer the resulting insights and the fuller and more complex the emerging account of reality - the more we are able "to look the truth in the face" and hold rather than reduce the ambiguities of existence, the more we are able to shape the

5 See, for example, Chala Chafiq, Rendez-vous iranien avec Simone de Beauvoir, DonnemarieDontilly, Éditions ixe, 2019; Nathalie Nya, Simone de Beauvoir and the Colonial Experience: Freedom, Violence, and Identity, Lanham, MD, Lexington Books, 2019; Manon Garcia, On ne naît pas soumise, on le devient, Paris, Flammarion, coll. "Climats," 2018. This year's Prix Simone de Beauvoir pour la liberté des femmes was given to Sarah Garcia Gross, an abortion rights activist from El Salvador. Angeline Montoya, "Le prix Simone de Beauvoir remis à une Salvadorienne pour son combat pour le droit à l'avortement," Le Monde, January 7 , 2019 .

6 For example, the World Congress of Philosophy instituted a new lecture series in Beauvoir's name. The inaugural Simone de Beauvoir lecture, "Gender in Translation/Beyond Monolingualism," was delivered by Judith Butler on August 13, 2013 in Beijing, China. 
future in liberating ways. ${ }^{7}$ As Anne Strasser explains in her article in this issue, “il s' agit de montrer le monde tel qu' il est, pour donner au lecteur l' envie de le changer." At the same time, we do not expect all of the discussions and encounters that take place within these pages to be harmonious; criticism, debate, and opacity are cornerstones of self-reflective engagement across cultures, perspectives, and social divides. Instead, we aim to create spaces where voices whose sounds have been muffled by official, conventional, and disciplined ways of listening can nonetheless be heard, and where traditional forms of thinking and writing can be viewed from fresh angles.

Whether coincidence or providence, there is much meaning to be found in the fact that Simone de Beauvoir Studies is being reborn in the very same year that Gallimard has announced that it will no longer publish Les Temps modernes, the monthly review that Simone de Beauvoir founded with JeanPaul Sartre, Maurice Merleau-Ponty, and others in October $1945 .{ }^{8}$ The loss of Les Temps modernes heightens the need for a cross-cultural, multidisciplinary, multigenre journal that "faces" — casts a direct regard (look) —at these modern times. Often forgotten in the long list of Beauvoir's achievements is her copious work as an editor, both for Les Temps modernes and for her friends and colleagues, who would entrust her with early drafts of their manuscripts. ${ }^{9}$ Regularly carrying out the duties of Editor in Chief of Les Temps modernes in practice if not in name, Beauvoir played a crucial role in fostering and delineating a number of avant-garde creative trajectories that later came to prominence in the twentieth century.10

Immediately following upon the departure of Les Temps modernes in linear time but also circling back to editorial commitments and innovations forged in the wake of World War II, Simone de Beauvoir Studies highlights cutting-edge

Simone de Beauvoir, The Ethics of Ambiguity, trans. Bernard Frechtman, New York, Citadel, 1976 [1948], p. 9. Subsequent references to this work are indicated by the abbreviation $E A$. "Le but des 'Temps modernes' était d' apporter une intelligence globale du monde," $L e$ Monde, May 2, 2019; Antoine Gallimard, "Pourquoi j' ai pris la décision d' arrêter les 'Temps modernes," Le Monde, May 22, 2019; Mitchell Abidor, “Les Temps Modernes': End of an Epoch," The New York Review of Books, May 17, 2019.

9 Simone de Beauvoir, Force of Circumstance, trans. Richard Howard, New York, Penguin Books, 1987 [1963], pp. 55, 125. Subsequent references to this work are indicated by the abbreviation $F C E$.

10 For example, in his article in this issue Jean-Louis Jeannelle writes, "Les Temps modernes ont joué un double rôle d'incubation et de légitimation, en plaçant en réseau des écrits de soi situés dans la proximité du genre du document que l'équipe dirigeante avait, dès le premier numéro de la revue, choisi de valoriser." See also Stève Bessac-Vaure, "Simone de Beauvoir as Mediator for Foreign Literature in Les Temps Modernes," in Simone de Beauvoir: A Humanist Thinker, ed. Tove Pettersen and Annlaug Bjørsnøs Leiden, Brill, 2015, pp. 5766. 
work that reveals and recognizes new modes of thinking and expressing for the purpose of understanding our current historical moment and countering prejudices and oppressions that curtail freedom. In words Beauvoir used to describe Les Temps modernes, we are a journal designed "to convey our positive commitment to the present" and "to reflect an epoch which [seeks] to know itself."1 This is a publication conceived for authors and readers who insist on being active participants in their own lives and time.

\section{$1 \quad$ New Faces / Nouveaux regards}

The title of this issue has multiple significations. Most obviously, it alludes to the Studies' new design whose focus is the signature cover image that features a sketch of Beauvoir's face in profile drawn by Alberto Giacometti in 1946. That the journal's new look invokes the year 1946 is no coincidence; this was the year that Beauvoir decided she would write The Second Sex. ${ }^{12}$ This same year Beauvoir published her third novel, All Men are Mortal, as well as three pivotal essays in Les Temps modernes: "Literature and Metaphysics," “An Eye for an Eye," and the first two installments of The Ethics of Ambiguity. Beauvoir's passions for travel and experiencing cultures other than her own also take root at this time: during 1946 she visited Tunisia, Algeria, Switzerland, Italy, and the Netherlands, and made plans to spend the first four months of 1947 in the United States. ${ }^{13}$ The defining features of Beauvoir's oeuvre crystalize during this historic year, when the aftermath of World War II and the consequences of having lived through an impossible history mark the period's writing and thinking, and spark political visions of a different future for the individual, society, nation, and world.

The journal's new cover recalls these formative moments in history and in Beauvoir's intellectual and political trajectory. In so doing, it announces that Simone de Beauvoir Studies is a place designed to harbor the kinds of creative energies, political engagements, and authentic expressions characteristic of

\footnotetext{
11 FCE, pp. 22, 55. See also Jean-Paul Sartre, "Présentation," Les Temps modernes, no. 1, October 1945, 1-21, p. 19.

12 FCE, pp. 195-196. See also Sylvie Le Bon de Beauvoir, "Chronologie," in Mémoires, t. I, dir. Jean-Louis Jeannelle and Éliane Lecarme-Tabone, Paris, Gallimard, coll. "Bibliothèque de la Pléiade," 2018, LV-CIII, pp. XC-XCI. Beauvoir had the idea for The Second Sex in mind in June 1946 and she began writing in October of that year.

13 Le Bon de Beauvoir, "Chronologie," pp. XC-XCI.
} 
Beauvoir's writing and thinking. The cover design symbolizes a time of creative ferment and foment amid deep self-reflection, a time when projects completed in the past are being realized and shared with others, a time when nascent projects are bubbling up, agitated and active, full of the potential to challenge and transform conventional patterns of thought and expression long into the future.

It is no accident that the cover image features a sketch of Beauvoir rather than a photograph, and a profile rather than a head-on view. A sketch is a beginning - something to be shaped and polished, something to show to others and refine while in dialogue with them, something from which to build and sculpt the next creation. Reality overflows our expressions of it and we must be wary so as not to confuse a concept or a string of words with the whole of things, with a concrete, singular, living being. ${ }^{14}$ Giacometti knew this lesson well. After the war, Giacometti devoted his art to the project of sculpting the human face. ${ }^{15}$ As Beauvoir explains in The Prime of Life, "A face, [Giacometti] told us, is an indivisible whole, a meaningful and expressive unity; but the inert material of the artist, whether marble, bronze, or clay is, on the contrary, capable of infinite subdivision - each little separate bit contradicts and destroys the overall pattern by the fact of its isolation."16 Giacometti's sketch of Beauvoir's face reminds us to attend to what is missing in our theories and stories, just as the sculptor must work through negative space and absence to find the positive expression of a figure in a block of stone or clay.

The patches of plaster finger-painted over the sculptor's sketch imbue the cover with a sensuality that breathes life and feeling into the two-dimensional representation. The plaster literally gives texture and depth; it calls the reader's whole body by inciting a corporeal equivalence between vision and touch, by suggesting we place our own fingers in Giacometti's grooves. Metaphorically, these traces of mortar implicate the material process of creation, the dynamic,

14 As Beauvoir writes, "reality overflows anything that can be said about it; instead of reducing it to symbols capable of verbal expression, we should face it as it is-full of ambiguities, opaque, and impenetrable." The Prime of Life, and ed., trans. Peter Green, New York, Lancer Books, 1973 [1962], p. 173, translation modified. Subsequent references to this work are indicated by the abbreviation $P L$. See also PL pp. 44, 733; Simone de Beauvoir, "Literature and Metaphysics," trans. Veronique Zayteff and Frederick M. Morrison, in Simone de Beauvoir: Philosophical Writings, ed. Margaret A. Simons with Marybeth Timmerman and Mary Beth Mader, Urbana, IL, University of Illinois Press, 269-277, pp. 270, 275.

15 Beauvoir was a favored model for Giacometti's project. The Alberto Giacometti database has catalogued four sketches and eight tiny sculptures in plaster and bronze of Beauvoir's face, all dated 1946. https://www.fondation-giacometti.fr/en/database. 
relational dimensions of an artist's life and work, the discarded remainders that underlie a finished product. The new face/nouveau regard of Simone de Beauvoir Studies channels this simple impulse at the heart of Beauvoir's life-project: "For an instant it seemed to me important to take plaster, or words, and create something." ${ }^{17}$

In addition to the cover, a number of other changes to the format and design of Simone de Beauvoir Studies work together to give the journal its new face/nouveau regard. For the first time in its thirty-five year history, the Studies is now available in digital format as well as its traditional print version. This decision to digitize the journal reflects the steadily increasing demand for easily accessible and globally-available resources that engage Beauvoir's oeuvre, as well as those that fall under the wider rubric of "Beauvoir studies." The phrase "Beauvoir studies" not only designates creative expressions that directly investigate Beauvoir's texts, but also those that do not treat these texts per se but nonetheless pursue themes relevant to Beauvoir's legacy such as gender, sexuality, race, feminism, and existentialism. As of December 2019, 377 articles that were published in the first twenty-nine volumes of Simone de Beauvoir Studies between 1983 and 2014 are available digitally for the first time. They will soon be indexed in relevant databases and repositories so that they appear immediately in online searches by students, researchers, and the general public. Digitization can now be added to the list of other technological advances that the journal has embraced throughout its history, including the switches from typed manuscripts to electronic files and from staples to bindings that were enacted in volume 13 ( $S d B S$ 13), published in 1996. Referring to the technological transitions on display in what she called the "lucky thirteen" issue, Yolanda Patterson exclaims, "We hope you like our new look!"18 Unlike these moves to electronic files and bindings, however, digitization has not replaced the journal's historical format. The new face/nouveau regard of Simone de Beauvoir Studies is multiple, at once digital and organic, holding the two aspects together in the present configuration, accommodating reading strategies tied to the screen as well as those linked to the printed page.

Still other changes have been implemented in the shift from the first and second phases of Simone de Beauvoir Studies. For example, in order to broaden the digital searchability and overall accessibility of works featured in the journal and to cultivate the exchange of ideas between Anglophone and Francophone audiences, the Studies now includes abstracts in both English and French and

$17 \quad F C E$, p. 625

18 Yolanda Astarita Patterson, "Editor's Foreword," Simone de Beauvoir Studies, vol. 13, 1996, p. 1 . 
a list of keywords with each published text. Moreover, Simone de Beauvoir Studies has transitioned from an annual to a semi-annual publication with a fixed publication schedule; each volume will contain two issues rather than one, and, beginning in 2020 with volume 31, these issues will be released in April (no. 1) and October (no. 2) respectively. The October issue will be a special issue whose contributions speak to a common theme selected by a guest editor or team of guest editors who has special expertise in the topic at hand. The inclusion of guest-edited special issue is intended to ensure that the Studies functions as a venue for au courant writing that is responsive to contemporary debates and questions. In addition, each issue of Simone de Beauvoir Studies now contains three book reviews that are substantive in length and highlight the latest publications relevant to Beauvoir studies.

Beyond the journal's new design, the title of this issue is suggestive of the shifting social, cultural, and geographical locations of authors and scholars who are working in the field. The current renaissance in Beauvoir studies is quite literally full of new faces who bring fresh questions and perspectives to its core themes. The next generation of Beauvoir scholars is rising. Those students who are presently pursuing graduate work in Beauvoir studies come from the first generation of Beauvoir scholars to have grown up networked, linked with immediacy through technological mediums to people and information from faraway places. Furthermore, the twenty-first century feminist turn away from the project of identifying a universal category of "woman" and toward that of engaging the particularity of women according to differential experiences of culture, race, nationality, class, sexual orientation, gender, ability, and so on, has affected the ways that Beauvoir is interpreted, received, and engaged by readers, as well as who is participating in the conversation. ${ }^{19}$

19 See, for example, Patricia Hill Collins, "Simone de Beauvoir, Women's Oppression and Existential Freedom," in A Companion to Simone de Beauvoir, ed. Laura Hengehold and Nancy Bauer, Oxford, Wiley-Blackwell, 2017, pp. 325-338; Alia Al-Saji, "Material Life: Bergsonian Tendencies in Simone de Beauvoir's Philosophy," in Differences: Rereading Beauvoir and Irigaray, ed. Emily Anne Parker and Anne van Leeuwen, New York, Oxford University Press, 2017; Stephanie Rivera Berruz, "At the Crossroads: Latina Identity and Simone de Beauvoir's The Second Sex," Hypatia, vol. 31, no. 2, 2016, pp. 319-333; Emily S. Lee, "Postcolonial Ambivalence and Phenomenological Ambiguity: Toward Recognizing Asian American Women's Agency," Critical Philosophy of Race, vol. 4, no. 1, 2016, pp. 56-73; Kyoo Lee, "Should My Bum Look Bigger in This? - Re-Dressing the Beauvoirian Femme," Women's Studies Quarterly, vol. 41, no. 1/2, 2012, pp. 184-193; Kathryn T. Gines (Kathryn Sophia Belle), "Sartre, Beauvoir, and the Race/Gender Analogy: A Case for Black Feminist Philosophy," in Convergences: Black Feminism and Continental Philosophy, ed. Maria Davidson, Kathryn T. Gines (Kathryn Sophia Belle), Donna Dale Marcano, Albany: State University of New York Press, 2010, pp. 35-51. 
Connected to the motivation to broaden and diversify the collective of people interested in Beauvoir studies, publication in the journal is now open to authors who are not members of the International Simone de Beauvoir Society. The first phase of the Studies limited publication opportunities to the Society's membership, and thus serves as a detailed record of what members of the Society were thinking about generally and discussing at the Society's annual conferences. The journal's current structure places no limits on who can submit their work for publication, mingling pieces by Society members with those authored by "new faces" - writers and artists from a variety of other social, economic, cultural, and geographical locations who may arrive at Beauvoir studies intermittently, engaging conversations in relation to certain issues and at particular points in time.

The ten authors whose writing is featured in the inaugural issue of the renewed Simone de Beauvoir Studies collectively expose questions and themes that animate our era; their subjects reflect twenty-first century preoccupations and express a modern and globalized world. Reading through the issue as a whole, four prominent and related threads can be seen to weave through these texts. That these topics are laced throughout French and English contributions alike is suggestive of their cross-cultural import and shared world-historical context, while the different ways that they surface across these groupings also indicate their cultural and social specificity.

The following themes are visible, although not equally obvious, in Beauvoir studies today and throughout the contributions in this issue: 1. encroachment (empiètement), 2. the twenty-first century self, 3. race and the reach of Beauvoir's "woman," and 4. metareflections and paratexts. Let us take each of these ideas in turn and consider how they demonstrate a "positive commitment to the present" and speak to the many dimensions of twenty-first century existence.

\subsection{Encroachment}

The philosophical concept of "empiètement," often translated into English as 'encroachment,' signals the inescapable mutual influence between one's own freedom and that of others. Encroachment designates the constitutive relationality of interiority and exteriority, self and other, and the individual and her social and historical context; it is a stepping on (an entwined step), a giving up of oneself, a gradual transgression of boundaries. Understood in this sense, 
encroachment is a theme that touches all of Beauvoir's writings, from her novels and memoirs to her philosophical essays, and from her early diaries to the last interviews of the 1980 os. However, this concept has not been named as such by Beauvoir scholars, nor has this term been associated with Beauvoir's texts themselves. This gap in the literature is surprising given Beauvoir's use of the term in The Blood of Others, and in light of its potential to serve as a true hallmark of Beauvoir's philosophy. ${ }^{20}$

Emmanuel de Saint Aubert's chapter, "Le Sang des autres: Merleau-Ponty et Simone de Beauvoir," first published in 2004 in his book Du lien des êtres aux éléments de l'être. Merleau-Ponty au tournant des années 1945-1951, has been chosen as the Simone de Beauvoir Studies Featured Translation / Traduction annuelle of 2019 in virtue of its importance to the field and its potential to incite interdisciplinary and cross-cultural dialogues. It is published here in English translation and serves as the lead article of this special issue. De Saint Aubert argues that Merleau-Ponty's phenomenological concept of encroachment is in fact "properly Beauvoirian." With reference to a number of MerleauPonty's unpublished manuscripts, including the Mexico Lectures of 1949 and the preparatory notes for The Visible and the Invisible, de Saint Aubert traces Merleau-Ponty's understanding of encroachment to Beauvoir's second novel, The Blood of Others. His analysis reveals that Merleau-Ponty makes fourteen references to Beauvoir's text in his unpublished working notes from 1945 to 1949, even though he does not mention The Blood of Others in his published works. ${ }^{21}$ Moreover, de Saint Aubert maintains that Merleau-Ponty "borrows" a number of other philosophical insights from Beauvoir, including his notions of "pensée du survol" (high-altitude thinking) and projection, as well as a certain critique of the French rationalist tradition that is first presented in Pyrrhus and Cineas. ${ }^{22} \mathrm{He}$ also exposes a tension or "ambivalence" present in Beauvoir's earliest philosophical works: the inevitability of the encroachment of freedoms that Beauvoir describes in The Blood of Others is at odds with the idea of a free-

20 Simone de Beauvoir, Le Sang des autres, Paris, Gallimard, 1945, p. 55, p. 110. See also La Force de l'âge, Paris, Gallimard, coll. "Folio," 1986 [196o], p. 619. In the first two cases, "empiéter" is rendered in the English as 'infringe' and 'trespass' respectively, and in the third it is rendered as 'encroach.' Simone de Beauvoir, The Blood of Others, trans. Yvonne Moyse and Roger Senhouse, New York, Penguin, 1948, repr. 1975 [1945], pp. 57, 115; PL, p. 652. Subsequent references to The Blood of Others are indicated by the abbreviation $\mathrm{BO}$.

21 Simons's article in this issue likewise discusses how Sartre writes that he is inspired by ideas from Beauvoir's She Came to Stay in his war diary, but fails to cite this influence in his publications.

22 See also Michel Kail's discussion of Beauvoir's rejection of the "roman de survol" in his review of Mémoires in this issue. 
dom that could sufficiently protect itself from encroachment found in Pyrrhus and Cineas, an essay that Beauvoir wrote after the novel and that de Saint Aubert believes reflects the new influence of Sartre's conception of freedom from Being and Nothingness.

Despite the field-shaping insights of de Saint Aubert's research and despite the fact that his article was first published fifteen years ago, his work has scarcely been referenced in Beauvoir studies until recently. ${ }^{23}$ One possible explanation for this oversight is that historically, on both sides of the Atlantic, Beauvoir has not for the most part been read as a philosopher. The failure to recognize and translate technical phenomenological terms and phrases that Beauvoir employs such as "conscience," "expérience vécue," "réalité humaine," "chair," "se faire être," and "empiètement" into English in ways consistent with their English usages in canonical philosophical texts tends to distort and obscure Beauvoir's philosophical contributions as well as her intellectual lineages and legacies. ${ }^{24}$ As Beauvoir emphasizes in her September 1985 interview with Margaret A. Simons, "I've studied a lot of philosophy, I have a degree in philosophy, I've taught philosophy, I'm infused with philosophy [...]."25 At the same time that it is problematic not to frame Beauvoir as a philosopher, the fact that Beauvoir's oeuvre evades clear categorization into institutionallysanctioned disciplinary categories is part of what is distinctive about it. ${ }^{26}$ Beau-

23 See Jennifer McWeeny, "Beauvoir and Merleau-Ponty," in A Companion to Simone de Beauvoir, ed. Laura Hengehold and Nancy Bauer, Oxford, Wiley-Blackwell, 2017, pp. 211223 .

24 On the use and translation of phenomenological terms in Beauvoir's writings, see Margaret A. Simons, "The Silencing of Simone de Beauvoir: Guess What's Missing from The Second Sex?" Women's Studies International Forum, vol. 6, no. 5, 1983, pp. 559-564; Simone de Beauvoir and Margaret A. Simons, "Two Interviews with Simone de Beauvoir," trans. Jane Marie Todd, Hypatia, vol. 3, no. 3, 1989, pp. 11-27; Toril Moi, "While We Wait: Notes on the English Translation of The Second Sex," Signs, vol. 27, no. 4, 2002, pp. 1005-1035; "The Adulteress Wife," London Review of Books vol. 32, no. 3, 2010, pp. 3-6; Sara Heinämaa, Toward a Phenomenology of Sexual Difference: Husserl, Merleau-Ponty, Beauvoir, Lanham, MD, Rowman \& Littlefield, 2003; Nancy Bauer, "Simone de Beauvoir: The Second Sex (Review of the New Translation)," Notre Dame Philosophical Reviews, 2011, https://ndpr.nd .edu/news/the-second-sex/;Jennifer McWeeny, "The Second Sex of Consciousness: A New Temporality and Ontology for Beauvoir's 'Becoming a Woman," in "On ne naît pas femme: on le devient ...": The Life of a Sentence, ed. Bonnie Mann and Martina Ferrari, New York, Oxford University Press, 2017, pp. 231-273; "Beauvoir and Merleau-Ponty."

25 Beauvoir and Simons, "Two Interviews with Simone de Beauvoir," p. 20.

26 On this point, see Meryl Altman, "The Grand Rectification: Review of The Second Sex by Simone de Beauvoir, translated by Constance Borde and Sheila Malovany-Chevalier," The Women's Review of Books, vol. 27, no. 5, 2010, pp. 3-6. See also Karen S. McPherson, "Simone 
voir's engagement with and relevance to a range of disciplines, themes, genres, and bodies of scholarship, and her widespread yet variable reception within a number of fields - not to mention her significant popularity outside of academia and her differential place in Francophone and Anglophone literaturesmeans that not all Beauvoir enthusiasts are reading the same sources at the same time. This is how gaps and pockets in the literature can occur, how the majority of Beauvoir scholars would miss de Saint Aubert's chapter on Beauvoir's notion of encroachment.

The idea to publish a translation of an article of crucial importance that warrants a wider, international readership each year and bestow it with the title of the Simone de Beauvoir Studies Featured Translation/Traduction annuelle was inspired by de Saint Aubert's work on Beauvoir. ${ }^{27}$ It is thus only fitting that Emmanuel de Saint Aubert be the first recipient of this honor. Because of the length and import of de Saint Aubert's article, we have decided to publish it in two installments. Part I, "I Exist, Therefore I Encroach," is presented in this issue. Part II, "Between Birth and Death: Freedom Struggling with Existential

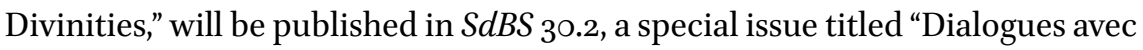
Beauvoir/Beauvoir in Conversation." It considers the origins of existentialism and their relation to myth with reference to the multidirectional personal relationships among Beauvoir, Merleau-Ponty, Zaza (Élisabeth Lacoin), and Sartre.

\subsection{The Twenty-First Century Self}

Due to its capacity to evoke the inevitable permeability of borders, encroachment is a twenty-first century concept if ever there was one. Encroachment is not intersubjectivity; in encroachment there is real danger that the self will be infected or subsumed by the other, that the very ontology of the self will be changed. In the third millennium, minds are always at risk of intellectual infections and other encroachments since they are wired to continuous streams of information that come through appendages like phones, screens, watches, and television. More than three hundred years after it was formulated, John Locke's classic theory of personal identity has never-imagined implications

de Beauvoir: Generic Boundaries Transgressed," Simone de Beauvoir Studies, vol. 7, 1989, pp. 6-12; Annlaug Bjørsnøs, "La Vieillesse — une approche interdisciplinaire. Thèmes, arguments et méthodes," Simone de Beauvoir Studies, vol. 26, 2009-2010, pp. 47-61; Stella Sandford, "Beauvoir's Transdisciplinarity: From Philosophy to Gender Theory," in A Companion to Simone de Beauvoir, ed. Laura Hengehold and Nancy Bauer, Oxford, WileyBlackwell, 2017, pp. 15-27.

27 Publishing translations as a means to cultivating cross-cultural exchange is a practice used in the first issues of Les Temps modernes. See Richard Wright, "Le feu dans la nuée," I and II, trans. Marcel Duhamel, Les Temps modernes, no. 1, October 1945, pp. 22-47; no. 2, November 1945, pp. 291-319. See also Bessac-Vaure, "Simone de Beauvoir as Mediator." 
because "the reach of consciousness" now extends beyond the body into data sets and information. Human memories are presently stored in clouds and online caches rather than in the head or under the skin. ${ }^{28}$ Separating one's own fate from the fates of others is also difficult in a context where economies, politics, environmental damages, and imperialisms are globalized.

Technologies of genetic enhancement, genetic modification, medical advancement, sex change operations, and artificial intelligence open us to new ontologies of cyborgs, transhumanism, organ transplants, sex-reassignment, and panpsychism. An entire political and philosophical literature has recently been built around the notion of nonhuman agencies; it includes those discourses that have been variably labeled "new materialisms," "speculative realisms," "neo-vitalisms," and "object-oriented ontologies." ${ }^{29}$ Traditional philosophical problems concerning the relationships between mind and body, consciousness and nature, human and machine, self and world are not only being reconfigured, but shaken to their very core. ${ }^{30}$

Fear about either the loss of self or irreversible transformations of self within ontologies of the twenty-first century may be partly responsible for mounting interest in the genres of autobiography and memoir, and other kinds of writing about the self. ${ }^{31}$ For example, Margaretta Jolly explains the current rise of "life

28 Andy Clark and David J. Chalmers, "The Extended Mind," in The Extended Mind, ed. Richard Menary, Cambridge, MA, The MIT Press, 2012, pp. 27-42.

29 Quentin Meillassoux, Après la finitude. Essai sur la nécessité de la contingence, Paris, Éditions du Seuil, 2006; Karen Barad, Meeting the Universe Halfway: Quantum Physics and the Entanglement of Matter and Meaning, Durham, NC, Duke University Press, 2007; Jane Bennett, Vibrant Matter: A Political Ecology of Things, Durham, NC, Duke University Press, 2010; Diana Coole and Samantha Frost, eds., New Materialisms: Ontology, Agency, and Politics, Durham, NC, Duke University Press, 2010; Timothy Morton, Hyperobjects: Philosophy and Ecology after the End of the World, Minneapolis, University of Minnesota Press, 2013; Graham Harman, Object-Oriented Ontology: A New Theory of Everything, New York, Pelican, 2018.

30 Donna J. Haraway, Modest_Witness@Second_Millenium.FemaleMan $\odot$ _Meets_OncoMouse $^{\mathrm{m}:}$ : Feminism and Technoscience, New York, Routledge, 1997; Jean-Luc Nancy, L'Intrus, Paris, Éditions Galilée, 200o; Andy Clark, Natural-Born Cyborgs: Minds, Technologies, and the Future of Human Intelligence, New York, Oxford University Press, 2004; Jacques Derrida, The Animal that Therefore I Am, trans. David Wills, New York, Fordham University Press, 2008 [2006]; Lori J. Shrage, ed., You've Changed: Sex Reassignment and Personal Identity, New York, Oxford University Press, 20og; Rosi Braidotti, The Posthuman, New York, Polity, 2013; Susan Schneider, Artificial You: AI and the Future of Your Mind, Princeton University Press, Princeton, NJ, 2019.

31 For descriptions of these genres and trends, see Margaretta Jolly, Encyclopedia of LifeWriting: Autobiographical and Biographical Forms, vol. 1, New York, Routledge, 2001; Alex Zwerdling, The Rise of the Memoir, New York, Oxford University Press, 2017; Peter Heehs, Writing the Self: Diaries, Memoirs, and the History of the Self, New York, Bloomsbury Academic, 2018. 
writing" as follows: "As the individualism unleashed by capitalism cracks and reshapes in the fire of globalization and the communications revolution, a literature that foregrounds the shape of a single life and its span seems to focus the anxieties of the age."32 In our contemporary contexts, the questions Beauvoir asks in Pyrrhus and Cineas are as relevant as ever: "We must cultivate our garden,' says Candide. This advice will not be much help to us because what is my garden? [...] So how to know what is mine?"33 So too, perhaps, are the answers she gives throughout her oeuvre, and especially those discussed and demonstrated in her memoirs.

Jean-Louis Jeannelle's article, "Simone de Beauvoir et l' autobiographie existentialiste: une réévaluation," enters this conversation by arguing that we have largely underestimated the weight of Beauvoir's contribution to "les écrits de soi." Jeannelle observes that we are just beginning to realize the enormous scope and complexity of Beauvoir's project of writing the self, which crosses literary forms and spans her correspondences with Sartre and Nelson Algren, her novels, and her political commitments, as well as her explicitly autobiographical writings. ${ }^{34}$ He maintains that Beauvoir's practice of writing the self is unique, even within the constellation of existentialist writings on the self including those of Sartre, Michel Leiris, Jean Genet, André Gorz, Violette Leduc, and others. Traditional conceptions of autobiography emphasize the interiority of the subject; the psychological development of the self as an individual; and the literary identity of the author, narrator, and main character of the text, a promise to readers known as "the autobiographical pact."35 As Alex Zwerdling explains, "[life stories] focus on the author's inner life rather than place in the world." ${ }^{36}$ These standard accounts miss many of the innovations of Beauvoir's memoirs, and especially the genius of her first attempt in the genre, Memoirs of a Dutiful Daughter, which not only blurs the lines between memoir and novel, but also foregrounds the external (that is, social and historical) aspects of the protagonist's life. Beauvoir's text thus inverts the presumed ideal of the genre by tracking the protagonist's development away from interiority

32 Margaretta Jolly, Encyclopedia of Life Writing, p. ix.

33 Simone de Beauvoir, "Pyrrhus and Cineas," trans. Marybeth Timmerman, in Philosophical Writings, ed. Margaret A. Simons with Marybeth Timmerman and Mary Beth Mader, Urbana, IL, Illinois University Press, 2004 [1944], 89-149, p. 91. See also de Saint Aubert's discussion of Candide's garden in this issue. See also Jo-Ann Pilardi, Simone de Beauvoir Writing the Self: Philosophy becomes Autobiography, Westport, ст, Greenwood Press, 1999.

35 Philippe Lejeune, Le Pacte autobiographique, Paris, Éditions du Seuil, coll. "Poétique," 1975.

$36 \quad$ Zwerdling, The Rise of the Memoir, p. 1. 
and into relationships, and specifically into the bond between Simone and her best friend, Zaza.

Whereas Jean-Louis Jeannelle argues that the individualist frame of the autobiographical pact prevents us from appreciating the significance of Beauvoir's autobiographical project, Anne Strasser finds Philippe Lejeune's notion useful for thinking the relationship between Beauvoir and her readers. In "Simone de Beauvoir et ses lecteurs: de personne à personne," Strasser assumes a radical approach to reading Beauvoir by attending to the "presence" of Beauvoir's readers across the six volumes of her memoirs. Notably, Strasser uses digital versions of Beauvoir's books to map her use of certain terms and show how Beauvoir's readers have influenced her writing in real time. Strasser's focus is the reader "à l'intérieur du texte" who is already in relationship with the author/narrator/character, rather than an imagined future reader who is presumed to watch the text from without. She argues that Beauvoir's concern with correcting misunderstandings of her life and her works, and her desire to speak to her readership are practices that mark her memoir project as an "institution de soi." ${ }^{37}$ In correcting and clarifying the image that her readers have of her, Beauvoir shapes her self-she makes herself loved (se faire aimer) and makes herself exist (se faire exister) —in the text and in reality. ${ }^{38}$ At the same time that Beauvoir is writing herself, however, her practice of writing works to involve the reader; to develop an authentic relationship with the reader that sees the reader as an active freedom who crafts a text together with its author in an act of collective enterprise. In Strasser's words, Beauvoir aims in her autobiography to "engager le lecteur, l'inciter à une prise de conscience, impliquer sa liberté dans l'acte de lecteur." In so doing, Beauvoir is embodying a rich and dynamic theory of literature.

If Beauvoir's descriptions of the self as a relational freedom who is situated historically and positioned socially is especially useful for making sense of twenty-first century existence, then perhaps this is because the unique demands of our era feminize all of us in the Deleuzian sense. ${ }^{39}$ Globalized capitalism and technological mediation push us to "become women" by empha-

37 See also Jean-Louis Jeannelle, "Les mémoires comme 'institution de soi,"” in Re-découvrir Simone de Beauvoir. Du Deuxième Sexe à La Cérémonie des adieux, ed. Julia Kristeva, Pascale Fautrier, Pierre Louis-Fort, and Anne Strasser, Paris, Éditions Le Bord de l' eau, 2008, pp. $73-83$.

38 Simone de Beauvoir, La Force de l'âge, Paris, Gallimard, coll. "Folio," 196o, p. 57; Tout compte fait, Paris, Gallimard, coll. “Folio," 1972, p. 634.

39 Gilles Deleuze and Félix Guattari, $A$ Thousand Plateaus: Capitalism and Schizophrenia, trans. Brian Massumi, Minneapolis, University of Minnesota Press, 1987 [1980], pp. 232309. See also Rosi Braidotti, "Becoming Women: Or Sexual Difference Revisited," Theory, Culture \& Society, vol. 20, no. 3, 2003, pp. 43-64. 
sizing the absence, withholding, and disunity of the subject, along with the inevitability of (our) encroachment. Beauvoir's early criticism of MerleauPonty's masculine notion of subjectivity may resonate with millennials too: "Woman, like man, is her body; but her body is something other than herself." In an era where enticements to conformity, immanence, and mechanism are legion - where we are consistently asked to sacrifice our autonomy for connection, where resistance to oppression is often in tension with participation in a global economy, it is no wonder that we would be nostalgic for an earlier time when the boundaries of self, agency, and body were clearer. It is no wonder that we would seek out artistic genres such as memoir, biography, auto-fiction, and confession.

\subsection{Race and the Reach of Beauvoir's "Woman"}

Though the feminization of subjectivity may be pervasive in the twenty-first century, we are not all sexed in the same ways, nor do we experience the harms of sexism and misogyny equally. As the concept of "intersectionality" was designed to show, other classifications such as race, class, nationality, sexuality, and ability structure the ways that our sexes are lived first-personally and perceived in the third-person; forgetting these constitutive relationships in theory and practice enables the invisibility and erasure of women of color and of Black women, in particular. ${ }^{41}$ In a neo-colonial, global world organized by lines of imperialism and colonial legacies that proliferate as much through popular culture and the internet as they do through formal economic policies and national agendas, we are all racialized to some degree, albeit in different ways and according to different cultural contexts and meanings.

40 Simone de Beauvoir, The Second Sex, trans. Constance Borde and Sheila Malovany-Chevallier, New York, Knopf, 2010 [1949], p. 41. Subsequent references to this work are indicated by the abbreviation $s s$.

41 For more on intersectionality, see River Collective, "A Black Feminist Statement," in This Bridge Called My Back: Writings by Radical Women of Color, ed. Cherríe Moraga and Gloria Anzaldúa, New York, Kitchen Table Women of Color Press, 1981 [1979], pp. 210-218; Angela Y. Davis. Women, Race, and Class, New York, Random House, 1981; bell hooks, Ain't I a Woman?: Black Women and Feminism, Boston, South End Press, 1981; Akasha (Gloria T.) Hull, Patricia Bell Scott, and Barbara Smith, eds., All the Women Are White, All the Men Are Black, But Some of Us Are Brave, New York, The Feminist Press, 1982; Audre Lorde, Sister Outsider, Berkeley, CA, Crossing Press, 1984; Deborah K. King, "Multiple Jeopardy, Multiple Consciousness: The Context of a Black Feminist Ideology," Signs, vol. 14, no. 1, 1988, pp. 42-72; Kimberlé Crenshaw, "Demarginalizing the Intersection of Race and Sex: A Black Feminist Critique of Antidiscrimination Doctrine, Feminist Theory, and Antiracist Politics," University of Chicago Legal Forum, vol. 1, no. 8, 1989, pp. 139-167; Patricia Hill Collins, Black Feminist Thought: Knowledge, Consciousness, and the Politics of Empowerment, Boston, Unwin Hyman, 199 . 
A unique text in Beauvoir's corpus for many reasons, America Day by Day includes Beauvoir's most direct discussions of race and racism. Here Beauvoir observes that white Americans often approach "the race question" in bad faith; they either deny that racism exists or that it is a problem, and they cultivate ignorance about the conditions of Black people's lives and the ways that white people benefit concretely from perpetuating discrimination against Black people. ${ }^{42}$ Even talking about race fuels guilt in white audiences; "it provokes discomfort in everyone."43 Beauvoir also notices that white Americans who enjoy frequenting Black dance halls and jazz clubs, and who openly reject racism, often erect racist imaginaries through attitudes of exoticism:

These whites define blacks as the antithesis of American civilization. Magnificently gifted in music and dance, full of animal instincts (including an extraordinary sensuality), carefree, thoughtless, dreamers, poets, given to religious feeling, undisciplined, childish-that's the conventional image of blacks that these whites readily construct. And they "are drawn to" blacks because they have projected onto them what they would like to be but are not. ${ }^{44}$

In philosophical terms, the concept of Blackness plays a fundamental role in the formation and maintenance of white identity and subjectivity.

Confining ourselves to the text of America Day by Day, it is somewhat unclear where Beauvoir locates herself in her analysis of white peoples' relationships with "the race question." Does thinking about race create discomfort for her as a white woman? Is she drawn to Black people because she imagines them as the "antithesis of civilization," antidotes to the bourgeois values and etiquette that she has fought to reject? Alternatively, perhaps she feels that her friendship with Richard Wright and her openly anti-racist and anti-colonial politics position her outside of the group of white people who would feel guilty about racism or exotify Black people? Perhaps her status as a French woman protects her from such responses since France does not have the same historical relationship with slavery as the United States does?

Beauvoir has been criticized, especially by American scholars, for upholding a view of woman that is grounded in the experiences of bourgeois, white

42 Simone de Beauvoir, America Day by Day, trans. Carol Cosman, Berkeley, CA, University of California Press, 1999 [1948], p. 236. Subsequent references to this work are indicated by the abbreviation $A D D$.

$43 \quad A D D$, p. 235.

$44 \quad A D D$, pp. $345^{-346 .}$ 
women and excludes or ignores the experiences of Black women, Latina women, Asian women, Muslim women, poor women, women from developing nations and the Global South, as well as queer women and trans women. ${ }^{45}$ Beauvoir's use of "the race-gender analogy" in the introduction to The Second Sex has also been identified as a mechanism that perpetuates the actual and theoretical invisibility of Black women. ${ }^{46}$ That women of color are engaging Beauvoir's ideas in their writing — whether critically, affirmatively, or creatively — and that they are doing so with increased frequency is significant in itself because it suggests that there is something about Beauvoir's work that opens conversations about race, even if this opening is still too narrow. Such conversations hold much promise for exposing truths of our time and resisting multiple oppressions.

Janine Jones's article "When Black Female Presence in L'Invitée Is (Seemingly) Not Invited to The Second Sex," provides a different way to engage Beauvoir's oeuvre on the question of race. Jones's method is less oriented toward criticizing Beauvoir's conception of "woman" for being too narrow or exclusionary than it is about making explicit the role of race in Beauvoir's theory of sexed subjectivity. Like Strasser, Jones employs a reading strategy that looks for "presences" in Beauvoir's texts. In both cases, "presences" are evocations of beings that inhabit the background of the narrative, plot, or theory but are nonetheless central to its development. Jones focuses on Beauvoir's first novel, L'Invitée (She Came to Stay), and identifies a "character" of sorts that has not yet been noted or discussed in the relevant scholarship: "Black female presences." These presences include the Black dancers at the Bal Colonial, the pretty créole man who lives in Xavière's apartment building, and Lise Malan, whom Françoise and Xavière perceive to be of mixed race. Jones calls these characters "presences" for they are decidedly not women or people according to their place in the text itself: they provide the sensuous and object-like elements of the plot—-sounds, smells, colors, and textures - and they are not subject to the same ontology of humanity or sexual difference that white women are. ${ }^{47}$ Although Beauvoir may

\footnotetext{
45 See note 22.

46 See King, "Multiple Jeopardy," pp. 43-46; Collins, "Simone de Beauvoir"; Gines, "Sartre, Beauvoir, and the Race/Gender Analogy"; bell hooks, "True Philosophers: Beauvoir and bell," in Beauvoir and Western Thought from Plato to Butler, ed. Shannon M. Mussett and William S. Wilkerson, Albany, NY, State University of New York Press, 2012, pp. 227-236.

47 For more on this last point, see Anne McClintock, Imperial Leather: Race, Gender, and Sexuality in the Colonial Conquest, New York, Routledge, 1995; Oyèrónké Oyewùmí, The Invention of Woman: Making an African Sense of Western Gender Discourses, Minneapolis, University of Minnesota Press, 1997; María Lugones, "Heterosexualism and the Colonial/Modern Gender System," Hypatia, vol. 22, no. 1, 2007, pp. 186-209.
} 
not have intended this consequence, this notion of "Black female presences" is one way of fleshing out her claim in The Second Sex that "not every female human being is necessarily a woman." ${ }^{48}$ According to Jones, Black female presence "does the work of philosophy" in Beauvoir's metaphysical novel; it provides a fixed point of "the timeless, absolute, objective world of Blackness" that illuminates the particular complexities and ambiguities of white women's anxieties, subjectivities, and pathways to transcendence.

In America Day by Day, Beauvoir claims that the most important element of racial and racist thinking is the idea that "the white race must maintain its purity."49 Jones's analysis reveals that She Came to Stay is rife with imagery of (racial) purity and (racial) contamination. Immediately after Xavière suggests that she and Françoise go to "le bal nègre", Françoise voices her desire for a thin, translucent candy that she admires for being "so dry and pure." 50 In response, and with an implication not lost on Françoise, Xavière says, "But I loathe purity."51 Curiously, de Saint Aubert's discussion of The Blood of Others emphasizes a parallel passage. Jean Blomart's childhood is described as follows: "translucent and pure [blanc] in front of the white page, he smiled at a beautiful, rational future." ${ }^{52}$ Later in life, after experiencing the war and the Occupation, Jean realizes that the moral purity that he aspired to in his youth is not only unattainable in the real world - a world of ambiguity, encroachment, love, and violence - but it is often appealed to by pacifists as a means to mask their moral culpability and responsibilities. Evocations of blood disrupt aspirations to purity (whether racial or moral) in both texts. To use Jones's phrase, the threat of "consanguineous contamination" that follows from encroachment destabilizes conventional values, subjectivities, and ontologies. Jeannelle's reference to Frantz Fanon's descriptions of the concept "sale nègre" as catalyst to

48 ss, p. 3. Beauvoir's placement of the chapter, "The Lesbian," resonates with Monique Wittig's claim that "lesbians are not women" since it situates the analysis of the lesbian in part I of the text, "Formation," about stages of development before one becomes a woman and not in part II, "Situation," which details strategies women use to navigate their womanhood. Monique Wittig, "On ne nait pas femme," Questions Féministes, vol. 8, May 1980, $75^{-84}$, p. 83. In the chapter, "From Maturity to Old Age," Beauvoir also suggests that old women are no longer women: "now she becomes a different being, asexual but complete: an elderly woman." ss, p. 626 .

$49 A D D$, p. 240.

50 Simone de Beauvoir, She Came to Stay, trans. Yvonne Moyse and Roger Senhouse, New York, W.W. Norton \& Company, 1954 [1943], p. 246, translation modified. Subsequent references to this work are indicated by the abbreviation scs.

$5^{1} \quad s c s$, p. 246.

$5^{2} \quad$ вO, pp. 12-13, translation modified. 
an "affective tetanization" offers another example of ideological connections between race, pollution, infection, and the foundations of white civilization. ${ }^{53}$

At the same time that Beauvoir's ideas invite contemporary conversations about race and racism, we should not expect the racisms of today to look the same as they did in the 1940s when Beauvoir wrote She Came to Stay and America Day by Day. Social, legal, and political power differentials that accompany different forms of racialization motivate denial and concealment of the problem(s); racist systems are continually transforming themselves so that they can perpetuate themselves into the next era. Contemporary racisms often function covertly without any mention of the term "race"; they can operate through restrictions on immigration or trade, derogatory attitudes toward nationalities or geographic regions that have high proportions of people of color, state prohibitions of certain cultural or religious practices, and the fortification of borders between neighborhoods and among nations.

\subsection{Metareflections and Paratexts}

More than ninety years after Beauvoir's penned one of her earliest published writings - the August 6, 1926 entry of her diary —we have now entered a late phase of Beauvoir scholarship. ${ }^{54}$ Early encounters with a thinker's work often aim at understanding the meaning of a text in isolation or in the context of one genre, discipline, or theme. ${ }^{55}$ In subsequent stages, scholars' views start to broaden and they begin to interpret the writer's ideas within the frame of her entire oeuvre, noting repetitions, contradictions, and thematic developments throughout the author's writing as a whole. ${ }^{56}$ They also look at the historical

53 Frantz Fanon, Black Skin, White Masks, trans. Richard Philcox, New York, Grove Press, 2008 [1952], pp. 89, 92.

54 Simone de Beauvoir, Diary of a Philosophy Student, Volume 1: 1926-1927, ed. Barbara Klaw, Sylvie Le Bon de Beauvoir, and Margaret A. Simons, Urbana, IL, University of Illinois Press, 2006, pp. 53-56.

55 See, for example, Suzanne Lilar, Le Malentendu du Deuxième sexe, Paris, Presses Universitaires de France, 1969; Claire Cayron, La Nature chez Simone de Beauvoir, Paris, Gallimard, 1973; Elaine Marks, Simone de Beauvoir: Encounters with Death, New Brunswick, NJ, Rutgers University Press, 1973; Daniel Armogathe, Le Deuxième Sexe. Analyse. Critique, Paris, Hatier, 1977; Elizabeth Fallaize, The Novels of Simone de Beauvoir, New York, Routledge, 1988.

56 See, for example, Anne Lasocki, Simone de Beauvoir ou l'entreprise d'écrire: essai de commentaire par les textes, The Hague, Nijhoff, 1971; Terry Keefe, Simone de Beauvoir: A Study of Her Writings, London, Harrap, 1983; Debra B. Bergoffen, The Philosophy of Simone de Beauvoir: Gendered Phenomenologies, Erotic Generosities, Albany, State University of New York Press, 1997; Nancy Bauer, Simone de Beauvoir, Philosophy \& Feminism, New York, Columbia University Press, 2001; Margaret A. Simons, Beauvoir and "The Second Sex": Feminism, Race, 
context of a writer's corpus and invoke comparisons with other writers. ${ }^{57}$ Applications of the writer's ideas to contemporary issues also appear later in the progression of engagement. ${ }^{58}$ Scholarly editions of the writer's works, along with anthologies and journal issues, turn up around this time. ${ }^{59}$ Very advanced stages exhibit metareflections; for example, they include considerations of the reception and evolution of a writer's ideas as they travel through different academic, cultural, linguistic, and historical contexts. ${ }^{60}$ They also attend to the interplay of a writer's life, texts, and theories, and they look to unpublished and lesser-known manuscripts and correspondence. At this point, scholars sometimes speculate about the personal and psychological motivations behind a

and the Origins of Existentialism, Lanham, MD, Rowman \& Littlefield, 20o1; Sonia Kruks, Simone de Beauvoir and the Politics of Ambiguity, New York, Oxford University Press, 2012.

57 See, for example, Sylvie Chaperon, Les Années Beauvoir (1945-1970), Paris, Fayard, 2000; Heinämaa, Phenomenology of Sexual Difference; Christine Daigle and Jacob Golomb, eds., Beauvoir and Sartre: The Riddle of Influence, Bloomington, IN, Indiana University Press, 20o8; Emily Anne Parker and Anne van Leeuwen, eds., Differences: Rereading Beauvoir and Irigaray, New York, Oxford University Press, 2017; Lori Jo Marso, Politics with Beauvoir: Freedom in the Encounter, Durham, NC, Duke University Press, 2017.

$5^{8}$ See, for example, Jacques J. Zéphir, Le Néo-féminisme de Simone de Beauvoir. Trente ans après Le Deuxième Sexe: un post-scriptum, Paris, Denoël Gonthier, 1982; Jean-Pierre Boulé and Ursula Tidd, eds., Existentialism and Contemporary Cinema: A Beauvoirian Perspective, New York, Berghahn Books, 2012; Julia Kristeva, Beauvoir présente, Paris, Fayard/Pluriel, 2016; Andrea Duranti and Matteo Tuveri, eds., Proceedings of the 18th Conference of the Simone de Beauvoir Society: Yesterday, Today, and Tomorrow, Newcastle Upon Tyne, Cambridge Scholars, 2017; Nya, Beauvoir and the Colonial Experience; Garcia, On ne nait pas soumise.

59 See, for example, Margaret A. Simons, ed., Feminist Interpretations of Simone de Beauvoir, University Park, PA, The Pennsylvania State University Press, 1995; Elizabeth Fallaize, ed., Simone de Beauvoir: A Critical Reader, New York, Routledge, 1998; Claudia Card, ed., The Cambridge Companion to Simone de Beauvoir, Cambridge, Cambridge University Press, 2003; Ingrid Galster, ed., Simone de Beauvoir: Le Deuxième Sexe, le livre Fondateur du féminisme moderne en situation, Paris, Honoré Champion, 2004; Margaret A. Simons, The Beauvoir Series, 7 vols., Urbana, IL, Illinois University Press, 2004-2019; Laura Hengehold and Nancy Bauer, eds., A Companion to Simone de Beauvoir, Oxford, Wiley-Blackwell, 2017; Jean-Louis Jeannelle, ed., Simone de Beauvoir, "Mémoires d'une jeune fille rangée”, Rennes, Presses Universitaires de Rennes, coll. "Didact Concours," 2018; Simone de Beauvoir, Mémoires, 2 vols., ed. Jean-Louis Jeannelle and Éliane Lecarme-Tabone, Paris, Gallimard, coll. "Bibliothèque de la Pléiade", 2018.

6o See, for example, Lorraine Hansberry, "Simone de Beauvoir and The Second Sex: An American Commentary," in Words of Fire: An Anthology of African-American Feminist Thought, ed. Beverly Guy-Scheftall, New York, The New Press, 1995, pp. 128-142; Michel Kail, Simone de Beauvoir philosophe, Paris, Presses Universitaires de France, 20o6; Tove Pettersen and Annlaug Bjørsnøs, eds., Simone de Beauvoir: A Humanist Thinker, Leiden, Brill, 2015; Bonnie Mann and Martina Ferrari, eds., 2017, “On ne naît pas femme: on le devient ...": The Life of a Sentence, New York, Oxford University Press, 2017; Chala Chafiq, Rendez-vous iranien. 
writer's views. ${ }^{61}$ Famous male authors are frequently the recipients of this full cycle of scholarly approaches, while scholarship about famous women is often truncated at one of the earlier stages. That Simone de Beauvoir Studies is one of the few journals in the world devoted to the vision and legacy of a woman author attests to this difference. ${ }^{62}$

The phases of encounter with a writer are not necessarily linear, nor are they always distinct from one another. However, the current emphasis on metareflections and paratexts in Beauvoir studies is indicative of the depth of engagement that readers of Beauvoir have collectively achieved over time. "Metareflections" ask how and why Beauvoir's work has been studied, interpreted, and received in the ways that it has, and they consider her texts and ideas from multiple cultural and social angles. They include reflections on Beauvoir's own metareflections-her descriptions of herself and her writings. "Paratexts" are elements such as the title, author's name, preface, cover design, and footnotes that accompany a text and that facilitate the relationship between author and reader. ${ }^{63}$ Paratexts also encompass what Gérard Gennette has called "epitexts"; statements about the text that are external to the text itself such as those made by the author in interviews, lectures, journals, letters, and autobiographies. ${ }^{64}$

New practices of reading and writing in the twenty-first century problematize any clean distinction between reflection and metareflection, and text and paratext. Where ideas come from, who receives them, which demographics are most likely to resonate with them, and how they are suppressed or spread are metareflective questions that accompany the use of online media and new

61 Carol Ascher, Simone de Beauvoir: A Life of Freedom, Boston, Beacon Press, 1981; Deidre Bair, Simone de Beauvoir: A Biography, New York, Summit Books, 199o; Kate Fullbrook and Edward Fullbrook, Simone de Beauvoir: The Remaking of a Twentieth Century Legend, New York, Basic Books, 1994; Toril Moi, Simone de Beauvoir: The Making of an Intellectual Woman, 2nd ed., New York, Oxford University Press, 2009 [1994]; Éliane LecarmeTabone and Jean-Louis Jeannelle, eds., Simone de Beauvoir, Paris, Éditions de L'Herne, coll. “Cahiers de L'Herne," 2012; Kate Kirkpatrick, Becoming Beauvoir: A Life, London, Bloomsbury Academic, 2019 .

62 Others journals devoted to woman authors include Woolf Studies Annual, Edith Wharton Review, and George Eliot/George Henry Lewes Studies. Other than Simone de Beauvoir Studies and Arendt Studies, which was started in 2017, this author knows of no other journals dedicated to the thought and legacy of a woman philosopher, while dozens of male philosophers have journals named for them.

63 Gérard Genette, Paratexts: Thresholds of Interpretation, Cambridge, Cambridge University Press, 1997 [1987], p. 1. I am grateful to Pauline Henry-Tierney for drawing my attention to how fecund the consideration of paratexts is in relation to Beauvoir's work during conversations that took place at the "Le Deuxième Sexe Seventy Years On" conference she co-organized with Julia Bullock at Emory University October 25-26, 2019.

64 Ibid., p. 344. 
technologies of data collection and tracking. State investments in cyber security and digital marketing, policies of censorship and net neutrality, and the prevalence of hacking and leaking show just how important the apparatus that situates and distributes a text is. In a digital world where stimulating and trivial pieces of information are likely to go "viral," spreading through millions of readers in just days or hours, reflection is already metareflection, and the paratext may have outpaced the text itself. We are all concerned about being contaminated with propaganda; current reading trends employed in Beauvoir studies are also a habit of our time.

In "Beauvoir and The Second Sex: The Turning Point," Margaret A. Simons asks what is perhaps one of the most burning metaquestions of all in Beauvoir studies: What led Beauvoir to write The Second Sex? Simons first notes that Beauvoir has said remarkably little about how she came to create her magnum opus and suggests that this absence may be as telling as what is positively said about the book's origins, indicating causes that Beauvoir may not have wanted to discuss publically. The standard explanation holds that Beauvoir came to the question of women because she wanted to understand herself better. ${ }^{65}$ Both Simons and Jeannelle evoke the following passage in support of this account: "Last night I spoke to Sartre for a long time about a point that specifically interests me about myself: my 'femininity', and how I'm of my sex and in what way I'm not." 66 But Simons assumes a different attitude to Beauvoir's memoirs than Jeannelle; she is skeptical of the accuracy of some of their descriptions and even goes so far as to characterize memoir as a kind of "barrier" that may have prevented Beauvoir from expressing the truth. She explains that "writing her memoirs would be a problem [for Beauvoir]" because the genre would have her choose between "tell[ing] the full story of her philosophical achievements" and protecting Sartre. Simons pores over the paratextual evidence for answers, referencing diary entries, letters, and interviews by both Beauvoir and Sartre, and reveals tensions between claims from different genres. She concludes that Beauvoir likely encountered not one obstacle but a "series of obstacles" that helped her realize what it means to be a woman in a sexist society and inspired her to write about it. ${ }^{67}$

65 Beauvoir writes, "Wanting to talk about myself, I became aware that to do so I should first have to describe the condition of women in general." FCE, pp. 195-196.

66 Simone de Beauvoir, Wartime Diary, trans. Anne Deing Cordero, ed. Margaret A. Simons and Sylvie Le Bon de Beauvoir, Urbana, IL, University of Illinois Press, 2009 [199o], p. 133. See also $P L$, p. 503 .

67 For discussion of another "turning point" or "threshold" in Beauvoir's life, see Sylvie Le Bon de Beauvoir, "Simone de Beauvoir au seuil d'une nouvelle vie," Simone de Beauvoir Studies, vol. 12, 1995, pp. 5-7. 
The final article in this issue, "The Past Is an Appeal: Simone de Beauvoir Studies 1983-2014" by Meryl Altman, takes metareflection in Beauvoir studies to another level, marking the beginning of still a new phase in Beauvoir scholarship that attends to the movement of this scholarship over time. Altman's essay is a retrospective analysis of the first thirty years of Simone de Beauvoir Studies that describes the genesis of the International Simone de Beauvoir Society and its journal, the evolution of thematic and disciplinary contributions across the first twenty-nine volumes of the Studies, and major events and intellectual contributions that occurred within these pages during this time. In this sense, Altman offers metareflections upon metareflections that are grounded by a down-to-earth style. She reflects on the character and proportions of articles from different disciplines, the debates that have animated this publication from "the question of influence" between Beauvoir and Sartre to the controversy over the extent of Beauvoir's resistance to the Occupation, and prominent trends toward addressing "complexities of genre" and "intertextuality." Altman reminds us that Beauvoir was alive when the first two issues of Simone de Beauvoir Studies appeared and that $S d B S_{3}$, the memorial issue published in 1986, features a color insert of reprints of work from Hélène de Beauvoir's art exhibition at Stanford University in California, which was organized by the journal's Editor in Chief, Yolanda Patterson, at whose home Hélène was staying when she learned of her sister's death. ${ }^{68}$ Altman's retrospective provides an invaluable record of those concrete relationships on and off the page that have led the Society and the Studies to this particular point in time. Hers is not only a study of an archive, but an archive in itself, one that is motivated by feminist methods and that emphasizes "the social dimensions of remembering." 69 In reflecting on the first thirty years of Simone de Beauvoir Studies, we find that Beauvoir's memoirs are not really confined to the six volumes of her autobiography; they extend beyond books to the lives that she touched in person and in writing, and then to the lives that those people have touched with their writing in turn. This journal is a repository for these kinds of serendipitous connections and, insofar as "the past is an appeal to the future," an inspiration for many more to come.

As we celebrate the rebirth of Simone de Beauvoir Studies, it seems especially important to thank those who have made this moment possible. Our debt to

68 Patterson recalls this moment in detail in "A Word from Your Editor: Twenty Years ago this Spring," Simone de Beauvoir Studies, vol. 22, 2005-2006, pp. ii-iv.

69 Sue Campbell, Relational Remembering: Rethinking the Memory Wars, Lanham, MD, Rowman \& Littlefield, 2003, p. 8. 
Yolanda Patterson for cultivating this international and multi-disciplinary network of authors could only be paid by a future that deepens and expands the dynamic connections that she set in motion so many years ago. Sadly, Liliane Lazar, who was the Society's secretary-treasurer for more than thirty years, passed away while we were working to transition the journal to its current format. Together with Yolanda, Liliane shaped the very possibilities that we are now realizing and she is remembered with feelings of profound gratitude. In addition, a large number of individuals from all over the world have played crucial roles during the five-year interim between the publication of $S d B S 29$ and $S d B S 3$ o to ensure that the Studies would not only continue after Yolanda's retirement, but also thrive in its new format. The five-person Editorial Committee has worked tirelessly to establish editorial and production structures that can accommodate a digital world, while also fostering the kinds of diverse content and styles of expression that make the Studies a distinctive venue for publication. The thirty members of the journal's Editorial Board have consistently offered their support, time, and sage advice that led to this rebirth. Several anonymous reviewers provided evaluations of the many submissions that have been received to date and their comments helped to develop the journal's content and orientation. Appreciation is also due to the authors themselves who entrusted their work to the Studies at a time of change and who spur us to new thoughts with their writings and creations. President Tove Pettersen, SecretaryTreasurer Meryl Altman, and the other members of the Society's Board of Directors and Steering Committee have devoted long hours and creative energy to instituting an organizational structure that would persist through future editorial transitions so as to prevent interruptions in the journal's publication schedule. Special thanks are also due to Margaret A. Simons, Barbara Klaw, and Megan Burke for their roles in helping to digitize the first twenty-nine volumes of the Studies. Finally, the excitement and dedication displayed by the current membership of the International Simone de Beauvoir Society undoubtedly motivated the relaunch project through to this inaugural moment.

The vibrant web of relationships that surround and constitute Beauvoir studies past, present, and future reminds us that lineages are not necessarily linear. As feminist-physicist Karen Barad remarks, "Some of the greatest debts we have are to those who live in different times and spaces." ${ }^{\text {"0 }}$ Time circles. Philosophies come in and out of prominence depending on the epoch and milieu. Existence returns again and again to the same places even if it never repeats itself exactly or inhabits these places in the same way twice. In 2019, we find 
ourselves faced with many of the same questions that Beauvoir faced in the first half of the twentieth-century. It is thus no surprise that Beauvoir's ideas speak to us now, perhaps more loudly than they ever have. Beauvoir describes existentialism as "a practical and living attitude toward the problems posed by the world today" that "strives to hold both ends of the chain at the same time, surpassing [dépassant] the interior-exterior, subjective-objective opposition." ${ }^{71}$ The porous borders, infectious encroachments, hybrid ontologies, and digital texts that characterize twenty-first century life call out for a neo-existentialism, a philosophy of ambiguity and an expressive method that moves among disciplines, genres, and perspectives, and attends to the multidimensionality of modern.

The many new faces/nouveaux regards of Simone de Beauvoir Studies discussed here-from the journal's new design and digital format to the latest themes in Beauvoir studies and the changing groups of people who are engaging them-point to a final sense of the title of this special issue: What will the future face/regard futur of Beauvoir studies be? Where will the distinctive possibilities afforded by this multidisciplinary, multigenre, and multicultural venue lead? What new strategies will we develop for "rejecting oppression at any cost"? ${ }^{72}$ What conceptual and political landscapes will we "hunters of meaning" traverse next? ${ }^{73}$ Like Athena's emergence from the head of Zeus, we face our epoch born for a second time, seeking out its unique features and challenges, sketching and sculpting meaning, actively crafting an interconnected future.

$71 \quad$ Simone de Beauvoir, "What Is Existentialism?" trans. Marybeth Timmerman, in Philosophical Writings, ed. Margaret A. Simons with Marybeth Timmerman and Mary Beth Mader, 2004, 323-326, pp. 324-325. Essay first published in 1947.

$72 \quad E A$, p. 96.

73 This phrase refers to Sartre's description of the impetus for Les Temps modernes: "We would be hunters of meaning, we would speak the truth about the world and about our lives." Jean-Paul Sartre, "Merleau-Ponty Vivant," trans. Benita Eisler, in The Debate between Sartre and Merleau-Ponty, ed. Jon Stewart, Evanston, IL, Northwestern University Press, $1998,565-625$, p. 575. Essay first published in 1961. 